\title{
Public Legitimacy of Government and People's Political Participation: The Case of the 2020 West Sumatra Regional Election, Indonesia
}

\author{
Agung Marsallindo* \\ Gadjah Mada University, Indonesia
}

\section{Cici Safitri}

Andalas University, Indonesia

\begin{abstract}
West Sumatra is one of the Indonesian provinces that conducted the simultaneous regional elections in 2020. It was said that it had the highest rate of election vulnerability index in 2020 based on the indicators of assessment including political participation, socio-political context, free and fair elections, contest, and vulnerability due to the Covid-19 Pandemic. In West Sumatra, the three regional head elections in 2005, 2010, and 2015 show that public political participation decreased from $64 \%$ to $58 \%$. However, in the 2020 election, the voter turnout rate rose to $61.68 \%$. Therefore, this article analyzes how did the West Sumatra government build public legitimacy to increase public political participation in the 2020 election, which was held in the Covid-19 Pandemic with all its limitations? In doing so, it uses a literature study method. The collected data were analyzed according to the principles of the qualitative method. The results of this study indicate that public legitimacy of the 2020 regional election in West Sumatra was built by three actors in the consolidation of democracy in the gubernatorial election as follows: a) local government, b) election participants and c) election management institutions, each of which had strategic steps in restoring public trust in the election during the Covid-19 Pandemic.
\end{abstract}

\section{Keywords}

West Sumatra regional election, public legitimacy, Pandemic Covid-19

\footnotetext{
* Corresponding author:

Agung Marsallindo

Gadjah Mada University, Yogyakarta Province, Indonesia

Email: amarsallindo@mail.ugm.ac.id
} 


\section{Introduction}

Society has a central role in a democratic country, as Abraham Lincoln argued about democracy, which refers to the governance of people, by people, and for people (in Epstein 2011). In running a country, power and authority are obtained to run the wheels of governance. As the first requirement for the establishment of a state, people are given a basic right in the form of legitimacy given to the government, which plays an important role in running their country. This legitimacy in the procedural definition of democracy is manifested in the form of an electoral process that functions to determine who exercises power and control of the state (Schumpeter 2003). In this democratic process, there is a process of institutionalization so that the whole process reaches the status of social order, namely when power, authority, and legitimacy run simultaneously.

In Indonesia, this power is achieved through a general election process aimed to elect the president, parliament members, and regional heads. PP No. 6 of 2005 explains the reform of regional head elections, in which governors, mayors, and regents are directly by the people, whereas previously elected by DPRD members. In that year, the first Simultaneous Regional Head Elections (Pilkada) were held. Fifteen years later, precisely in 2020, Indonesia held its fourth Simultaneous Regional Head Elections in nine provinces and 270 regencies/cities throughout Indonesia. This time, the elections faced a special challenge in that they were carried out in the Covid-19 pandemic situation that hit the world. The government had postponed the election time twice because of this situation, but they finally determined that the election would be held on December 9, 2020 (Budilaksono 2020). But, civil society organizations such as Nahdlatul Ulama and Muhammadiyah opposed this government decision (Wicaksono 2020) arguing that people's participation and legitimacy would decrease because they were afraid to come to vote.

This article deals with the Simultaneous Regional Head Elections focusing on those held in the Province of West Sumatra in 2020 to vote the governor and mayors or regents in 13 regencies. West Sumatra, according to research conducted by the Election Oversight Agency (Bawaslu) of the Republic of Indonesia, was regarded as an area with the highest level of vulnerability in elections in Indonesia based on several criteria (Bawaslu RI 2020). This was based on vulnerabilities in the aspects of Social and Political Context, Free and Fair Elections, Contestation, Participation, and the Covid-19 Pandemic (Yamin 2020). Implementing the elections in West Sumatra Election faced the challenges of these potential vulnerabilities. In addition, the organizing agency had a burden in the form of a target 
set by the KPU to increase the rate of public participation from $58 \%$ in the 2015 gubernatorial election to $77 \%$ in 2020 (Zikri 2020). After the election process on December 9, 2020, was successfully carried out, the West Sumatra KPU recorded that the public participation rate in the Governor Election increased from the previous election to $61.68 \%$ (Zikri 2020). Although it did achieve the national target set by the KPU, at least this figure is better than the previous gubernatorial election. This indicates that the level of public trust and legitimacy in the Governor's Government increased by around $3.5 \%$, as evidenced by the enthusiasm of the community in the election despite the Covid-19 Pandemic and the threat of vulnerability in this election process.

Based on this, we assume that actors interested in consolidating democracy in West Sumatra have built public legitimacy as a form of increasing people's participation in the 2020 gubernatorial election process. As stated above, legally and formally, the implementation of elections is interpreted as a legitimate political mechanism to legitimize the elected political elite to occupy political positions in the form of the people's vote. Therefore, in this paper, we attempt to answer the question of how have the consolidating actors of democracy in the 2020 West Sumatra gubernatorial election built public legitimacy in increasing public participation in the 2020 elections?

This study uses descriptive qualitative methods to analyze how the consolidating actors of democracy in the 2020 West Sumatra Governor Election were able to build public legitimacy in increasing public participation in the 2020 elections. A descriptive analysis method is used to collect data and information on phenomena or actual problems through the process of data collection, compilation, processing, and concluding, which seeks to describe an objective empirical situation on the phenomenon or problem being studied. The data collection technique used in this study is a literature study due to the limitations of the researcher to conduct direct interviews with the informants (Creswell 2007).

A literature review is a critical and in-depth evaluation of previous research. A good literature review is done by evaluating new findings from scientific journal articles. It does not stop at the reading process alone as the researcher also summarizes, analyses, and makes a critical and in-depth synthesis of the articles reviewed (Wahono 2016). Besides, the data were obtained from reports (journals articles, and documentation related to the research problem) and were analyzed by the principles of the exploratory postpositive method. A large amount of data were reduced by making abstractions as a core summary. 


\section{Political Participation}

Many scholars have studied political participation. Meyliana and Erowati (2020) studied the people's political participation in the 2020 Tana Toraja Regency Regional Head Election (Pilkada). Tana Toraja Regency had to study the people's readiness for the 2020 Regional Head Election during the Covid-19 pandemic. Elections during the pandemic were full of debate because they could threaten public health, which would have implications for the level of public participation in the Regional Head Election. Therefore, public participation in exercising their right to vote, which is an indicator of the success of the local elections, had to be considered. Moreover, public participation in elections in Tana Toraja was in decline in previous years. Their study reveals that the low level of public participation in the 2015 Regional Head Election was due to the lack of political awareness and public trust in the government in anticipating conflicts between supporters of candidates. Furthermore, in the 2020 Regional Head Election during the pandemic was also predicted that there would be a decline in the people's participation in exercising their right to vote due to the high rate of Covid-19 cases.

Similarly, Wahyuningsih (2021) analyzed people's participation in the Simultaneous Regional Head Election during the Covid-19 pandemic in Semarang. Her study was aimed at exploring the level of community participation and its supporting and inhibiting factors. In contrast to the prediction by many experts and studies, her study reveals that the rate of people's participation in the Regional Head Election in Semarang increased more significantly than that in the previous year. Her findings show that when viewed nationally, the participation rate reaches $74.34 \%$ in Central Java Province and $68.62 \%$ in Semarang City. Factors that influenced this level of participation include the increasing public awareness, local election organizers who could ensure safety from the transmission of the coronavirus, and the high participation of novice voters. This made the city of Semarang achieve a fairly high level of public participation in the election. Public trust in the organizers in implementing the Regional Head Election was an important factor so that people were not mentally disturbed when they came to polling stations.

Compared to previous studies above, the difference and novelty of this study lie in the argument that despite the Covid-19, the consolidation of democracy actors and the good impression of the public on the performance of the West Sumatra provincial government increased the rate of people's participation in the 2020 Regional Head Election more significantly than that in the previous elections. 


\section{Public Legitimacy and Political Participation in West Sumatra}

We use the concept of legitimacy to analyze the success of actors in consolidating democracy in the West Sumatra gubernatorial election, which succeeded in increasing the rate of people's participation and obtaining high public legitimacy compared to the previous gubernatorial elections. According to Surbakti 2009, legitimacy in the practice of political power is very important because it is related to the legitimacy or acceptance of society towards the authorities or parties who have authority. Beetham (in Mas'udi 2017) states that legitimacy and the creation of legitimacy are central issues in social and political theory. It is at the core of any political organization to survive. Legitimacy is needed for both democratic and non-democratic political authority as a moral basis for enforcing rules and regulations and imposing public policies. Although many scientists define legitimacy differently, political scientists emphasize defining legitimacy and what constitutes legitimate or illegitimate power. The essence of legitimacy is about recognizing the right to rule. Based on this, looking at the increasing level of public legitimacy of West Sumatra in the 2020 gubernatorial election, we explain that the legitimacy was achieved through the consolidation of democracy actors. If we try to relate it to Peter G. Stillman's presentation (in Rothstein 2008) that describes legitimacy as the conformity of government outputs with relevant value system patterns from society, these outputs are not always related to desired or expected responses but also include unwanted or unexpected outcomes of the government's actions.

In the sense that the government or the actors of the consolidation of democracy certainly take actions that result in the process of increasing public legitimacy, and in this paper, the author will describe how the actions of these actors gave birth to an increase in community legitimacy in voter participation in the 2020 West Sumatra Governor Election.

\section{Government}

The Covid-19 pandemic hit the world and caused losses in many sectors of people's lives. The government is the main actor in overcoming this outbreak, starting from the central government to the regional governments in regions. The West Sumatra provincial government, in the process of handling Covid-19, tracing positive people with coronavirus, and doing the Covid-19 test, which was fast and on a large scale, received praise from various parties in Indonesia (Kemendagri 2020). The regulations for implementing free PCR Swab tests for the people of West Sumatra by the 
government are very beneficial for communities. The public's impression of policies of handling this pandemic had implications for public legitimacy to the government.

The public felt the existence of the government as an actor who had the authority and power to make policy on controlling the Covid-19 pandemic. As a result, the community satisfaction with the government increased. Although we did not find any research that explained that the Covid-19 policy in West Sumatra was able to increase the community satisfaction of the government, the enthusiasm of the community, and the government's ability to promote the process of preventing the spread of Covid-19 in this area were able to increase the people's legitimacy of government, in the sense that there was the sense of comfort and pride that the government brought to the community through the process of forming the legitimacy of the government (Routhstein 2008). The suitability of government work with what was desired by people resulted in public legitimacy. This impacted a sense of security among people to vote in the Covid-19 pandemic because the provincial government was prepared in preventing Covid-19 in West Sumatera. The people began to realize the important role of the Provincial Government, and, as a result, when there was a leadership change, they expressed their aspirations and voted for a leader who could at least show the same performance as the current leader.

The process of establishing legitimacy by the government of West Sumatra created a good impression that produced social order. Furthermore, if we look from the Government's point of view and its executive actor, the Governor of West Sumatra, Irwan Prayitno, it was recorded that Prayitno had campaigned for the governorship several times to the public. We see that when he was given legitimacy by the people due to his hard work during his leadership, he tended to get legitimacy from people in the gubernatorial election.

\section{Election Participants}

Based on data from the Election Supervisory Agency (Badan Pengawas Pemilu [Bawaslu]) of West Sumatra Province, in the West Sumatra Regional Head Election process on December 9, 2020, pre-election, election day, and post-election processes were carried out well and a few frauds were reported. Regarding the election vulnerability indicators made by the Bawaslu in the social and political aspects, in which security measures, state administrators' authority, and power relations at the local level had to be watched, we found all these run well (Yamin 2020). This resulted in a good public impression of the election so that people voted in the election. 
In addition, all four pairs of candidates targeted people of all ages, young and old. Audy Jonialdy of the candidate pair no. 4 Mahyeldi-Audy Jonaldy was the youngest candidate for deputy governor as he was 37 years old when he applied for the position. The other three pairs of candidates also targeted young people in their campaign attempting to get their votes in the election.

Therefore, all this eliminated the conservative gap that the politics is only for the old as seen in the presence of candidates from young people and the campaign that targeted youth. As a result, the process carried out by the Regional Head Election participants created public legitimacy to carry out the gubernatorial election and the increase in the rate of public participation. The output of the presence of the younger generation in the election process was that the young people believed that when they were part of the government, their interests would be prospered by these actors. So, this is in line with the type of legitimacy category (Surbakti 2009), one of them is Instrumental Legitimacy, that legitimacy comes from the process of the leader's agreement with the community to provide welfare in material form to get support and legitimacy from the community.

\section{Election Organizing Agency}

The Regional Head Election during the Covid-19 Pandemic provided challenges to the organizing institutions, KPU and Bawaslu. In response, they conducted large campaigns and promotion of elections. This was aimed at convincing people to vote and not be too afraid of the pandemic (Farisa 2020). This is also true for the West Sumatra KPU, which did a budget efficiency up to IDR11 billion, that still focused on campaigning to attract public participation (Saputra 2020) such as collaboration with local governments to promote this so that people felt safe to participate in the election (Watra 2020).

Furthermore, the view that that West Sumatra was a region with a high level of vulnerability in the elections as underlined by Bawaslu made the organizing institutions well-prepared to deal with potential problems (Shania 2020). As a result, the organizers appeared more assertive in carrying out their duties. For example, in the case of the rejection of an independent candidate who applied for running for governorship, the KPU, and other parties directly conduct an assessment or review of the decision of the West Sumatra KPU chairman in rejecting the independent candidate. Their finding showed that the KPU chairman was found to have violated the code of ethics and was immediately dismissed as the West Sumatra 
KPU chairman and transferred to be a regular commissioner (Agusmardi 2020). We see that the quick response of the organizers to internal errors convinced the public to trust the organizing agency. Based on research by Marsallindo (2019), it was found that acts of fraud committed by people were caused by the lack of firmness and distrust of the organizing agency in taking action against a problem. Through the large-scale promotion and responsiveness of the organizing institution in the West Sumatra gubernatorial election, the legitimacy of this institution was built.

This is in accordance with the concept of the validity of power by Heywood (2004) that says power must be exercised through formalized or standardized rules. These rules must be justified in terms of common good beliefs, namely a society that has legitimacy. In terms of the suitability of the regulations designed by the organizing agency, we think that it can create trust, and the output is that they think the level of fraud will be minimized. They confidently participate in the process of the 2020 gubernatorial election in West Sumatra.

\section{Conclusion}

This article has described that legitimacy is a political process given by people based on their assessment of the government as seen in the case of the 2020 regional head election in West Sumatra. In the process of forming this legitimacy, the government as an actor that has power and authority takes steps to realize the act of legitimacy. This legitimacy was possible due to the actors interested in consolidating democracy in the 2020 West Sumatera Gubernatorial Election. In the case of West Sumatera, a province with high vulnerability, the regional head election was carried out successfully due to democratic consolidation, particularly during the Covid-19 pandemic. The evidence was seen in the increase of people's participation in West Sumatra in the gubernatorial election in 2020 from $58 \%$ to $61.68 \%$.

This public legitimacy was obtained by the government through, first, actors who had an interest in the consolidation of democracy in the gubernatorial election. they managed to get the attention and sympathy of the people who were satisfied with the government's performance in the previous term, coupled with the national assessment of West Sumatra as being excellent in handling the Covid-19 pandemic, resulting in a proud community and a sense of security presented by the government. Second, public legitimacy was achieved because people believed that the gubernatorial election was equal for all groups as evidenced by candidates 
came from all ages including the younger generation, and all candidate pairs focused their campaign on young people. Third, the organizers received a good reception of their performance from the public before the election as they conducted a large scale of promotion of the election to persuade people to vote. As a result, there was an increase in the rate of people participating in the election. Public legitimacy was present in the 2020 West Sumatera regional head election and this indicated how people hoped for better leaders who govern their country.

\section{References}

Agusmardi. 2020. "Soal Pendaftaran Cagub Perseorangan, Amnasmen Dipecat dari Jabatan Ketua KPU Sumbar." Jurnalsumbar.com, November 4. Retrieved 1 October 2021 (https://jurnalsumbar. com/2020/11/soal-pendaftaran-cagub-perseorangan-amnasmendipecat-dari-jabatan-ketua-kpu-sumbar/).

Bawaslu RI. 2020. Indeks Kerawanan Pemilu (IKP) PILKADA Serentak 2020. Padang: Bawaslu.

Budilaksono, Imam. 2020. "Komisi II DPR Setuju Pilkada 2020 Dilaksanakan 9 Desember.” Antaranews.com, May 27. Retrieved (https://www.antaranews.com/berita/1518730/komisi-ii-dpr-setujupilkada-2020-dilaksanakan-9-desember).

Creswell, John W. 2007. Research Design, Qualitative, Quantitative, and Mixed Methods Approaches. Thousand Oaks, California: Sage.

Epstein, Richard A. 2011. "Direct Democracy: Government of the People, by the People, and for the People." Harvard Journal of Law \& Public Policy 34: 819-826.

Farisa, Fitria Chusna. 2020. "KPU Prediksi Biaya Pilkada 2020 Meningkat Jika Digelar di Masa Pandemi”. Kompas.com, May 26. Retrieved 1 October 2021 (https://nasional.kompas.com/ $\mathrm{read} / 2020 / 05 / 26 / 21513071 / \mathrm{kpu}$-prediksi-biaya-pilkada-2020meningkat-jika-digelar-di-masa-pandemi?page=all).

Heywood, Andrew. 2004. Political Theory An Introduction. Third Edition. New York: Palgrave Macmillan.

Kemendagri. 2020. "Mendagri Puji Penanganan Covid-19 di Sumatera Barat." Kemdagri.go.id, August 25. Retrieved 1 October 2021 (https://www.kemendagri.go.id/berita/baca/29160/mendagri-pujipenanganan-covid-19-di-sumatera-barat). 
Marsallindo, Agung. 2019. "Dampak Hate Speech dalam Pemilihan Kepala Daerah Kota Padang Tahun 2018." Padang: Universitas Andalas.

Mas'udi, Wawan. 2017. "Creating Legitimacy in Decentralized Indonesia: Joko 'Jokowi ' Widodo's Path to Legitimacy in Solo, 2005 - 2012." Melbourne: The University of Melbourne.

Meyliana, Inggried Fena and Dewi Erowati. 2020. "Menakar Partisipasi Politik Masyarakat Kabupaten Tana Toraja Terhadap Pemilihan Kepala Daerah (Pilkada) Tahun 2020." Jurnal Academia Praja 3(2):168-81.

Saputra, Wahyu. 2020. "KPU Sumbar Efisiensi Anggaran Pilkada 2020 Rp11 Miliar." Gatra.com, July 14. Retrieved 2 October 2021 (https://www.gatra.com/detail/news/484651/politik/kpu-sumbarefisiensi-anggaran-pilkada-2020-rp11-miliar-).

Schumpeter, Joseph A. 2003. Capitalism, Socialism, and Democracy. London: Routledge.

Shania, Tita. 2020. "Ketua KPU Sumbar: Pilkada Serentak 9 Desember 2020." Sumbarprov.go.id, July 14. Retrieved 3 October 2021 (https://sumbarprov.go.id/home/news/19051-ketua-kpu-sumbarpilkada-serentak-9-desember-2020).

Wahyuningsih, C. D. 2021. "Partisipasi Masyarakat pada Pemilihan Kepala Daerah Serentak Masa Pandemi Covid-19 di Kota Semarang." Public Service and Governance Journal 1-10.

Watra, Boyke Ledy. 2020. "KPU Ajak Pemda Sosialisasi Alasan Pilkada Dilanjutkan Saat Pandemi." Antaranews.com, June 19. Retrieved 3 October 2021 (https://www.antaranews.com/berita/1564032/kpuajak-pemda-sosialisasi-alasan-pilkada-dilanjutkan-saat-pandemi).

Wicaksono, Adhi. 2020. "Pilkada 2020, Potensi Rendah Partisipasi dan Minim Legitimasi." Cnnindonesia.com, September 22. Retrieved 4 October 2021 (https://www.cnnindonesia.com/ nasional/20200922065014-32-549179/pilkada-2020-potensi-rendahpartisipasi-dan-minim-legitimasi).

Yamin, Ilham. 2020. Indeks Kerawanan Pemilu (IKP) Pilkada Serentak 2020. Edited by Tim Editor Bawaslu RI. Jakarta: Bawaslu RI.

Zikri, Fuadi. 2020. "Meski Pandemi, Partisipasi Pemilih Pilgub Sumbar 2020 Meningkat." Padangkita.com, December 21. Retrieved 4 October 2021 (https://padangkita.com/meski-pandemi-partisipasipemilih-pilgub-sumbar-2020-meningkat/). 